\title{
The Figure of Apollos, Father of Dioscorus, in the Light of Coptic Letters From Sixth-Century Aphrodito
}

The village of Aphrodito in Middle Egypt, today known as Kom Ishgaw, was the location of several important papyrological discoveries which yielded many texts from the sixth, seventh, and eighth centuries that provide important information about daily life in a village of the Thebaid before and after the Arab conquest. The bilingual archive from Byzantine Aphrodito is made up of slightly more than 700 literary, semiliterary, and documentary texts including 75 Coptic texts (44 of them now edited, while 31 still remain unpublished). ${ }^{1}$ The documentary texts, which are of particular interest here, include many texts relating to the administration of the village of Aphrodito during the sixth century. The village's leadership in this century included the well-known figure of Dioscorus and, before him, his father Apollos. ${ }^{2}$ This archive is commonly known as the "Dioscorus archive" as Dioscorus, a notable of the village, landowner, notary and poet of his time, was originally considered to be its central figure. However, much of the documentation from the beginning of the sixth century actually relates to his father, Apollos. Until recently, Apollos' leadership upon the village as prōtokōmètēs, his travel to Constantinople, and his entrepreneurial activities in the countryside were based on Greek texts, and a synthesis of Apollos' life has been proposed by James Keenan. ${ }^{3}$

The archive's texts were written in Greek and Coptic by multiple individuals including Dioscorus himself, and some of them wrote texts in both languages. The letters, which constitute the bulk of the Coptic proportion of this bilingual archive, were long neglected (with the exception of MacCoull's transcriptions), ${ }^{4}$ but they have recently been rediscovered by a new generation of scholars. As part of ongoing research on the Coptic letters from Byzantine Aphrodito, I have recently reedited, or in some cases edited for the first time, many of these letters. ${ }^{5}$ Seven letters from this corpus give us additional information about Apollos' activities. ${ }^{6}$

\footnotetext{
1 Amongst others, see Bell (1944) for an introduction and Fournet (2008b) for more on the precise composition of this archive. In 2005, a colloquium in Strasbourg was dedicated to Dioscorus, and the resulting volume (Fournet/Magdelaine [2008]) provides an excellent overview of the Aphrodito archive from several perspectives.

2 The chronological extent of the Greek record ranges from 27 July 506 (P.Cair.Masp. I 67100) to 587/ 588 (P.Strasb. gr. inv. 1633; ed. pr. Fournet [2008a] 22-25).

3 Keenan (1984).

4 Mainly in MacCoull (1992) and (1993).

5 Vanderheyden (2015).

6 P.Coptic Museum inv. 4057; Pap.Berlin P. 11932; P.Ismailia inv. 2241; P.Cair.S.R. 3733.10, 17, 40a, and 40c (texts 1, 2, 3, 7, 8, 9, and 10 in Vanderheyden [2015] II 8-35 and 58-101).
} 
The first half of the sixth century saw Apollos occupying, sometimes concurrently, several different functions. He is first attested in 514, and probably died thirty-two years later, in 546/547. ${ }^{7}$ In addition to his well-known activities as a landowner and entrepreneur in Aphrodito and its surroundings, mainly attested in the Greek texts and studied by Keenan, ${ }^{8}$ he also occupied the function of village headman (prōtokō-

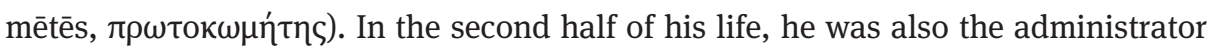

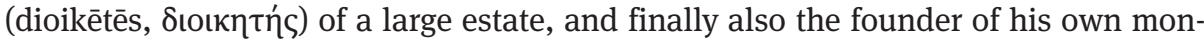
astery, as will be discussed below. During this period, it is possible to trace Apollos' life through its three distinct phases and map out his career on the basis of the Greek and Coptic sources. In a more private dimension, one of the Coptic letters also offers us a glimpse of his personality and of his life as a family man who cared about his children and other family members. In what follows, these different aspects of his career as well as aspects of his character will be presented. This will be followed by a brief examination of his handwritten Coptic texts, which not only provide the most vivid testimony from his life, but also represent a good starting point for considering the nature of his bilingualism.

\section{Apollos as Village Headman (prōtokōmētēs)}

Apollos is first attested as prōtokōmētēs in 514 (P.Flor. III 280). The Greek documentation shows that he continued to occupy this position alternately with his elder brother Besarion ${ }^{9}$ in the 520s and up to $530 .{ }^{10}$ In the early 530s, it seems that neither Apollos nor Besarion were involved with the village's administration. He appears as an ordinary individual in 532 (P.Lond.V 1691). In $536^{11}$ and $537^{12}$, Apollos was no more

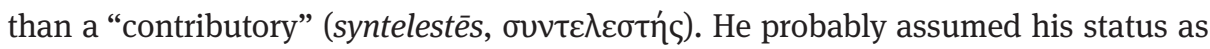
prōtokōmētēs around 538 with Aurelius Charisios ${ }^{13}$ and Bottos ${ }^{14} \cdot{ }^{15}$ His son, Senouthes ${ }^{16}$, seems to have joined him in this position in 540. ${ }^{17}$ Apollos' return to his function as prōtokōmētēs may possibly have arisen as a result of the additional prestige that he gained after founding his monastery. Deferential language used to

7 See Bell (1944) 26 and n. 21; Rémondon (1971) 775; Gascou (1977) 361; Keenan (1984) 957; introductions to the P.Vat.Aphrod. $7.33-34$ and P.Vat.Aphrod. $10.4 \mathrm{n}$ and 43.

8 See Keenan (1984) 960 - 962.

9 See Ruffini (2011) s.n. Besarion 1 (p. 95-96).

10 P.Cair.Masp. III 67329 (May-June 524); P.Cair.Masp. II 67125 (14 July 525); P.Lond.V 1690 (30 August 527); P.Cair.Masp. III 67301 (20 August 530).

11 P.Flor. III 283.

12 P.Ross.Georg. III 36.

13 See Ruffini (2011) s.n. Charisios 4 (p. 140 -141).

14 See Ruffini (2011) s.n. Bottos 5 (p. 136-137).

15 P.Cair.Masp. I 67052 (538); 67053 (538); II 67199 (ca. 538); 67264 (524/525 or 539/540).

16 See Ruffini (2011) s.n. Senouthes 1 (p. 533-534).

17 P.Cair.Masp. III 67323.5 (540 in BL XI 53). 
address him after this point, for example "most worshipful (sebasmiōtatos, $\sigma \varepsilon \beta \alpha$ $\sigma \mu \iota \dot{\omega} \tau \alpha \tau о \varsigma)$ Apa Apollos," supports such a suggestion, ${ }^{18}$ but we should also consider the influence of Count Ammonios, ${ }^{19}$ for whom Apollos worked, as Zuckerman explains. ${ }^{20}$ The sources also indicate that he certainly was prōtokōmētēs again in 543, along with his son Senouthes and his nephew, the priest Victor ${ }^{21}$, who was a son of Besarion's. ${ }^{22}$ In September 544, these three prōtokōmētai signed an acknowledgment of debt together. ${ }^{23}$

His visit to Constantinople as a prōtokōmētēs in the early 540s (probably in the winter of 540/541) was also a notable event in his life. It was highly unusual for a member of the rural elite of a small Egyptian village to travel to the imperial capital. Documented in P.Cair.Masp. II 67126, this journey is believed to be connected with Aphrodito's privileged tax status (autopragia), considering the stronghold Apollos' family had on the area in the 540s, thanks to Ammonios' authority. As suggested by Keenan, this could also have been a religious pilgrimage connected to the foundation of his monastery several years beforehand; Apollos traveled in the company of his nephew, the priest Victor, Besarion's son. However, neither hypothesis can currently be confirmed. ${ }^{24}$

Three Coptic letters addressed to Apollos could be added as new sources for the study of his status as prōtokōmètēs: P.Coptic Museum inv. 4057, Pap.Berlin P. 11932 and P.Ismailia inv. 2241. ${ }^{25}$ These three Coptic letters are addressed to Apollos and provide evidence for his role as prōtokōmètēs and, above all, as a mediator in three difficult cases that all seem to have been resolved at the local level. The first letter deals with the mediation of a conflict between two butchers. The second is a settlement in an affair involving an individual who appears to have been considered untrustworthy, perhaps concerning a loan. The third deals with fiscal and monastic problems. While the first text contains no indicators narrowing its dates down further than to what we know to have been the years of Apollos' activity (514-546/547), the second and third letters can be dated to between 538 and 546 on the basis of their use of the title "Apa" for Apollos.

\footnotetext{
18 PSI VIII 933.

19 See Ruffini (2011) s.n. Ammonios 1 (p. 17-19).

20 See Zuckerman (2004a) 48 about the P.Cair.Masp. III 67323.

21 See Ruffini (2011) s.n. Biktor 8 (p. 105-106).

22 P.Cair.Masp. III 67286.

23 P.Mich. XIII 669.

24 See Keenan (1984) 958.

25 See Vanderheyden (2015) II, texts 1, 2, and 3 (p. 8-35).
} 


\section{Apollos as the Founder of his own Monastery and a Secular Apa}

The monastery founded and endowed by Apollos (probably ca. 537-538) is attested in many texts from Aphrodito. Dedicated to the "Holy Christ-bearing Apostles," it was often referred to in the Byzantine period by the name of its founder, but some formulations combine both designations, such as "the recently founded monastery of the Holy Christ-bearing Apostles, named the Monastery of Apa Apollos,"26 "Monastery of the Christ-bearing Apostles called Pharoou/Pharau/Pharaous," ${ }^{27}$ or more simply "Monastery of Pharoou," probably due to its location on the outskirts of Pharoou, which is identified with the village of Minyat Farūh in the Arabic sources, although the precise localization of the monastery is still uncertain. ${ }^{28}$

Was Apollos a monk? The question arises from the titles he bears in various documents, and mostly from the title Apa, usually used during the Byzantine period to accompany names of clerics or monks. The attestation of Apollos as Apa Apollos, prōtokōmētēs in PSI VIII 933, dated in 538 brings into question his double status. This text indicates that Apollos had already founded his monastery while he was still exercising the function of prōtokōmètēs: he bears the honorific epithet of "very pious" (sebasmiōtatos) Apa Apollos. Similarly, in a grazing lease (P.Cair.Masp. I 67112), the shepherd-tenant calls Apollos, the owner, "your reverence" (1. 8) and later "your holiness" (1. 17). ${ }^{29}$ Keenan considered it possible that Apollos had been able to hold the two positions of monk and prōtokōmētēs simultaneously. ${ }^{30}$ Wipszycka has taken a contrary view and argues that the title Apa was no longer a marker of religious prestige at this time, but rather a more general marker of high social status. ${ }^{31}$ Wipszycka roundly rejects the possibility that Apollos could have been a monk and prōtokōmètēs at the same time, ${ }^{32}$ mostly because it would have been inappropriate given the asceticism expected of monks. ${ }^{33}$

In this light, the main contribution of the Coptic texts is to confirm that Apollos did indeed perform the functions of monastery founder and village headman concurrently. As a matter of fact, the address on the verso of the Coptic letter P.Ismailia inv. 2241 bears the name Apollos with the titles of Apa and prōtokōmētēs ana апо스 прфттоком[нтнс]. The body of the text refers to Apollos using monastic titles,

26 See P.Cair.Masp. I 67096.4-5 (573) and Wipszycka (2008) 262.

27 See P.Cair.Masp. I 67003.5 (567).

28 Timm (1984-1992) IV (1988), s.v. Minyat Farūh, 1658-1659.

29 P.Cair.Masp. I 67112.

30 See Keenan (1984) 958-959.

31 See Derda/Wipszycka (1994) 41-44.

32 Rejecting the belief shared by Maspero (comment on P.Cair.Masp. I 67064), MacCoull (1993) 24-25, and Keenan (1984). Cf. Wipszycka (2008) 265 and Vanderheyden (2015) 125-126.

33 See Derda/Wipszycka (1994) 42-44 and Wipszycka (2008) 266. 
which indicates that he had already founded his monastery at this stage: "honorable

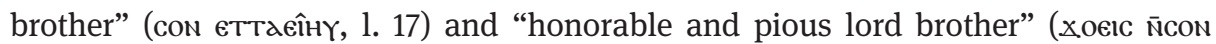

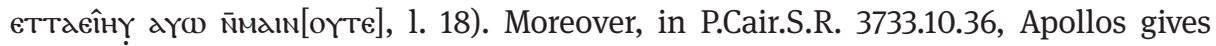
himself the title of "their humble father" (пеүїот мелахистос ${ }^{34}$ ) in the 540s, which could be an indication of his role as the founder of the monastery of Pharau, but he never bears the titles proestos or archimandritēs used for those at the top of the monastic hierarchy.

It seems likely, then, that Apollos was neither a monk nor a senior cleric or abbot, but rather a secular Apa, as Wipszycka argues: he was undoubtedly a founder, a benefactor, and perhaps even a resident of the monastery, but also, in his worldly life, one of the village headmen and the administrator of a large estate. This exceptional status is at present a unique case in the documentation concerning Egyptian monasticism. ${ }^{35}$

\section{Apollos as Administrator (dioikètēs) of a large Landowner}

For a century, scholars have labored to determine the identity of two homonymous characters attested in the archive of Aphrodito on the basis of the Greek documentation: Apollos the dioikētēs and Apollos the hypodektēs, both of whom worked for Count Ammonios. Both were identified at various times with Apollos, the son of Dioscorus and prōtokōmētēs of Aphrodito. ${ }^{36}$ Zuckerman was finally able to confirm the identification of Apollos, prōtokōmètēs of Aphrodito, with Ammonios' administrator (dioikētēs). ${ }^{37}$ The Coptic texts provide a more precise view of the daily functions of Apollos as a dioikētēs.

Four Coptic letters written by Apollos himself survive (P.Cair.S.R. 3733.10, 17, 40a, and 40c). These can be dated to July 545 because of a date explicitly mentioned in P.Cair.S.R. 3733.10. ${ }^{38}$ This date coincides with the dating of the accounting documents of Ammonios, which date from between 541 and $546 .{ }^{39}$ These four unpublished Cop-

34 See Vanderheyden (2015) II, text 7 (p. 63-80).

35 See Wipszycka (2008) 266 and Wegner (2017) 76 n. 5.

36 Maspero in the introduction of P.Cair.Masp. II 67138 (p. 23 and 26); Bell (1944) 24 n. 7; Rémondon (1971) 774-775; and Wegner (2017) 51, 60, and 62 argued that Apollos, the son of Dioscorus, was the Count's hypodektēs. Whereas Gascou (2008) 309-349 and Fournet (2001) 481-482 separately and subsequently in a joint article, Gascou/Fournet (2002) 28, demonstrated the opposite and proved that Apollos could not be the hypodektēs of Count Ammonios, but was rather his dioikētēs. Zuckerman (2004a) 48, 51, and note 56 identified the Count's hypodektēs with Apollos, son of Ioseph. 37 See Zuckerman (2004b) 77.

38 Line 34 provides a date, the 4th of Epiphi of the ninth indiction, i.e., 11 July, probably during the year 545.

39 See among others P.Cair.Masp. II 67138 and 67139. 
tic letters supplement the information provided by the Greek documents about Apollos' official functions. They are addressed to two people whose names are now lost, but who clearly had links to the properties of Count Ammonios: the letters repeatedly mention Ammonios' clients and some of his properties, designated by their toponyms. It is clear that Apollos had received training in the production of accounts: he writes an abbreviated account summary on the verso of letter P.Cair.S.R. 3733.40a and he quotes an extract from the cadaster of Phthla in P.Cair.S.R. 3733.10 (1. 10). These three letters do not concern the taxation process, which is well known from the Greek administrative documents, but rather contain instructions for the day-to-day management of properties. For instance, Apollos orders the recipients to go to various places and to meet certain people, to write letters, to collect rents, to "purify" (perhaps winnowing?) the corn and to collect tax receipts, to send food items or even to send a donkey! ${ }^{40}$

\section{Apollos as a Family Man}

In the Coptic letter P.Cair.S.R. 3733.40c, Apollos reproaches his addressees for not giving him any news. After the usual salutations, Apollos asks for the health of a certain Tekrompe ${ }^{41}$, whom Apollos calls "my daughter," but who is in fact his niece (she is known in the Greek texts under the double name of Anastasia-Tekrompe). Two of Apollos' sons, Dioscorus ${ }^{42}$ and Menas $^{43}$, are also mentioned. Tekrompe is well known because she married Phoibammon ${ }^{44}$, son of Triadelphos. In fact, their wedding was a great occasion and reunited two families from the local village elite. One could explain Apollos' strong attachment to Tekrompe (calling her "my daughter") by the fact that she was in his custody. Indeed, P.Cair.Masp. I 67026 mentions that Dioscorus, his siblings, his cousins Dioscorus ${ }^{45}$, and Tekrompe were all raised by Apollos in the same house. In fact, when Apollos' sister died, Dioscorus' cousins remained in the care of their uncle, who continued to manage their property together with his own and probably raised them as his own children.

\section{Apollos’ Coptic Handwriting}

As his only surviving physical trace, Apollos' writing allows us to observe him directly, almost 1,500 years after his death. Regarding his Greek handwriting, Keenan notes

\footnotetext{
40 See Vanderheyden (2015) II, texts 7, 8, and 9 (p. 63-97).

41 See Ruffini (2011) s.n. Anastasia 1 (p. 21).

42 See Ruffini (2011) s.n. Dioskoros 3 (p. 159-167).

43 See Ruffini (2011) s.n. Menas 43 (p. 377).

44 See Ruffini (2011) s.n. Phoibammon 1 (p. 447-449).

45 See Ruffini (2011) s.n. Dioskoros 31 (p. 170).
} 
that his literacy in Greek was not very good. ${ }^{46}$ The accounts that he wrote for Ammonios' properties show that he was able to write in Greek as well. However, Apollos was far from illiterate: the four letters that he wrote himself in Coptic had simply not been identified. In fact, these four letters enable a sufficiently precise identification of his Coptic style, on the basis of a comparison with his Greek style.

His Coptic writing is rather regular, straight, small, and bilinear. Few ligatures are employed, and systematic use is made of word separators. Apollos was able to write in Coptic and also to switch to Greek language and codes, as in the case of the Greek account embedded in Coptic syntax in P.Cair.S.R. 3733.40c verso. In fact, elements of his Greek hand (abbreviations, figures and fractions in particular) are identical with those which we find in the Coptic letters. Fig. 2 compares samples of his writing in different documents in Greek and Coptic. These elements establish that these two styles were produced by the same hand.

\begin{tabular}{|c|c|c|}
\hline & Coptic letters & Greek accounts \\
\hline 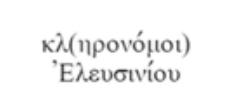 & 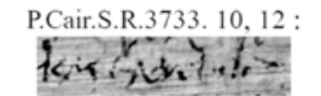 & $\begin{array}{l}\text { P.Cair.Masp. II } 67139, \mathrm{v}, \mathrm{v}^{\circ}, 5: \\
\text { Jescostsctwi? }\end{array}$ \\
\hline$\dot{\alpha} \delta \varepsilon \sigma \pi(o ́ \tau \alpha)$ & $\begin{array}{l}\text { P.Cair.S.R.3733. 10, } 11 \text { : } \\
\text { wi.tiz }\end{array}$ & $\begin{array}{l}S B \times x 14670,8: \\
\text { exechy }\end{array}$ \\
\hline$\dot{\alpha} \varphi^{\prime}(\hat{\omega} v) \dot{\varepsilon} \delta \delta^{\prime} \theta(\eta)$ & $\begin{array}{l}\text { P.Cair.S.R. } 3733.40 \text { (c), } 20 \text { : } \\
\text { Affufl: }\end{array}$ & 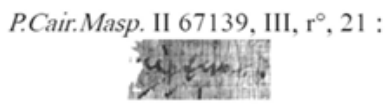 \\
\hline $\begin{array}{c}\text { vó }(\mu \sigma \mu \alpha) \alpha \pi(\alpha \rho \grave{\alpha}) \\
\delta \zeta\end{array}$ & $\begin{array}{l}\text { P.Cair.S.R. } 3733.40 \text { (c), } 20 \text { : } \\
\text { Wuttol }\end{array}$ & $\begin{array}{c}\text { P.Cair.Masp. II } 67138, \mathrm{I}, \mathrm{v}^{\circ}, 6 \text { : } \\
\text { Fitus }\end{array}$ \\
\hline 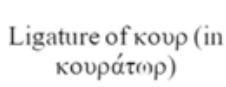 & 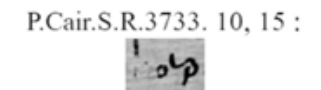 & $\begin{array}{c}\text { P.Cair.Masp. II } 67138, \mathrm{I}, \mathrm{r}^{\circ}, 2 \text { : } \\
k_{0} \mathrm{p}\end{array}$ \\
\hline
\end{tabular}

Fig. 2: Samples of his writing in different documents in Greek and Coptic

\section{Apollos' Bilingualism}

The mother tongue of Apollos' family was clearly Coptic. This fact has been established since the beginning of the twentieth century, primarily by Bell and Crum, albeit initially on the basis of now-obsolete ethnic criteria. ${ }^{47}$ Recently, Papaconstantinou

46 See Keenan (1988) 165.

47 See Bell/Crum (1925) 180-181 and Bell (1944) 24. 
advanced the hypothesis, based on one reedition of a Coptic letter, that Apollos probably received a Greek education..$^{48}$ The newly available documentation and the reinterpretation of P.Coptic Museum inv. 4057 invalidates this suggestion. Presuming (incorrectly) that Apollos was the sender of this letter (and not the addressee), Papaconstantinou concluded that Apollos was not able to use Coptic anymore. But Apollos was actually the addressee of this letter, as the text's rediscovery and his endorsement confirm. The verso of this letter preserves a clear Greek endorsement: ç

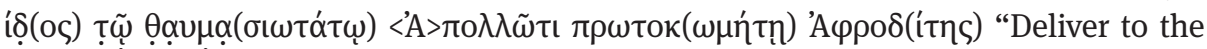
very admirable Apollos, prōtokōmētēs of Aphrodito". ${ }^{49}$ Consequently, the very nonstandard coloration of the letter cannot be attributed to his incompetence in Coptic. In fact, Apollos probably received an elementary education in Greek and Coptic, since he was able to write in each language. He was able to read the letters in Greek that he received, ${ }^{50}$ but his skills in Greek were not as good as his Coptic, which is both correct and very fluent.

In conclusion, I would like to emphasize that Apollos is, for the moment, the only example in our Byzantine evidence of a multifaceted individual involved in politics, monasticism, and local village management. Apollos was, in fact, simultaneously prōtokōmètēs, an administrator of Ammonios' belongings, and the founder of a monastery for the last ten years of his life (537-546/7). The Coptic texts presented here shed light on concrete aspects of Apollos' day-to-day tasks. Moreover, his Coptic letters provide additional information concerning the bilingualism of the village elite and offer us a rare example of a paleographic case study that exhibits specific traits for each language (particularly Greek-Coptic bigraphism). Apollos was probably more fluent in Coptic, his mother tongue, than in Greek, which he used mostly for business and administrative purposes but not for personal matters or in his daily life.

\section{Bibliography}

Bell/Crum (1925): Harold I. Bell and Walter E. Crum, "A Greek-Coptic glossary”, in: Aegyptus 6, $177-226$.

Bell (1944): Harold I. Bell, “An Egyptian village in the age of Justinian”, in: Journal of Hellenic Studies 64, 21-36.

Derda/Wipszycka (1994): Tomasz Derda and Ewa Wipszycka, "L'emploi des titres Abba, Apa, et Papas dans l'Égypte byzantine", in: Journal of Juristic Papyrology 24, 23-56.

48 See Papaconstantinou (2008) 79.

49 See Vanderheyden (2015) text 1 (p. 8-14).

50 He is the addressee of P.Cair.Masp. I 67064, probably of P.Lond. V 1684, and possibly of P.Cair.Masp. I 67065, P.Cair.Masp. III 67290, P.Lond. V 1681, and SB XX 14119. He is also among the addressees of P.Cair.Masp. I 67061 and probably P.Cair.Masp. I 67063, P.Cair.Masp. II 67199, and P.Cair.Masp. III 67323. 
Fournet (2001): Jean-Luc Fournet, “Du nouveau dans les archives de Dioscore d’Aphrodité”, in: Isabella Andorlini, Guido Bastianini, Manfredo Manfredi, and Giovanna Menci (eds.), Atti del XXII Congresso Internazionale di Papirologia. Firenze, 23-29 agosto 1998, Florence, $475-485$.

Fournet (2008a): Jean-Luc Fournet, “Archive ou archives de Dioscore? Les dernières années des 'archives de Dioscore”, in: Fournet/Magdelaine (2008) 17-30.

Fournet (2008b): Jean-Luc Fournet, “Liste des papyrus édités de l'Aphrodité byzantine” (Annexe 2), in: Fournet/Magdelaine (2008) 307-343.

Fournet/Gascou (2002): Jean-Luc Fournet and Jean Gascou, "Moines pachômiens et batellerie", in: Christian Décobert (ed.), Alexandrie médiévale 2 (Études Alexandrines 8), Cairo, 23-45.

Fournet/Magdelaine (2008): Jean-Luc Fournet and Caroline Magdelaine (eds.), Les archives de Dioscore d'Aphrodité cent ans après leur découverte. Histoire et culture dans l'Égypte Byzantine. Actes du colloque de Strasbourg (8-10 décembre 2005) (Collections de l'Université Marc Bloch - Strasbourg; Études d'archéologie et d'histoire ancienne), Paris.

Gascou (1977): Jean Gascou, Review of Pieter J. Sijpesteijn, The Aphrodite Papyri in the University of Michigan Papyrus Collection (= P.Mich. XIII), in: Chronique d'Égypte 52, 360-368.

Gascou (2008): Jean Gascou, “La table budgétaire d’Antaeopolis (P.Freer 08.45 c-d; SB XX 14494)", in: Fiscalité et société en Égypte Byzantine (Bilans de recherche 4), Paris, 309-349.

Keenan (1984): James G. Keenan, "Aurelius Apollos and the Aphrodite village élite”, in: Atti del XVII Congresso Internazionale di Papirologia. Napoli, 19-26 maggio 1983. III, Naples, 957-963.

Keenan (1988): James G. Keenan, “On languages and literacy in Byzantine Aphrodito”, in: Basil G. Mandilaras (ed.), Proceedings of the XVIII International Congress of Papyrology. Athens 25-31 May 1986. II, Athens, 161-167.

MacCoull (1992): Leslie S. B. MacCoull, "More missing pieces of the Dioscorus archive", in: Marguerite Rassart-Debergh and Julien Ries (eds.), Actes du IV Congrès copte. Louvain-la-Neuve, 5-10 septembre 1988. II: De la linguistique au gnosticisme, Louvain, $104-112$.

MacCoull (1993): Leslie S. B. MacCoull, "The Apa Apollos Monastery of Pharoou (Aphrodito) and its papyrus archive”, in: Le Muséon 106, 21-63.

Marthot (2013): Isabelle Marthot, Un village égyptien et sa campagne. Étude de la microtoponymie du village d'Aphrodité ( $V l^{e}-V I I I^{e}$ s.), unpublished doctoral dissertation, Paris, École Pratique des Hautes Études.

Rémondon (1971): Roger Rémondon, “Le monastère alexandrin de la Métanoia était-il bénéficiaire du fisc ou à son service?", in: A. Giuffrè (ed.), Studi in onore di Edoardo Volterra V, Milan, $769-781$.

Ruffini (2011): Giovanni R. Ruffini, A Prosopography of Byzantine Aphrodito (American Studies in Papyrology 50), Durham.

Vanderheyden (2015): Loreleï Vanderheyden, Les lettres coptes des archives de Dioscore d'Aphroditê (VI siècle, Égypte), unpublished doctoral dissertation, Paris, École Pratique des Hautes Études.

Wegner (2017): Joanna Wegner, Monastic Communities in Context. Social and Economic Interrelations of Monastic Institutions and Laymen in Middle Egypt (6th-8th Centuries), doctoral dissertation, University of Warsaw (electronic version available at <http://depotuw.ceon.pl/bitstream/handle/item/2077/3100-DR-H-121321.pdf〉).

Wipszycka (2008): Ewa Wipszycka, "Le monastère d'Apa Apollos. Un cas typique ou un cas exceptionnel ?", in: Fournet/Magdelaine (2008) 261-273.

Zuckerman (2004a): Constantin Zuckerman, Du village à l'Empire. Autour du registre fiscal d'Aphroditô (525/526) (Monographies du Centre de recherche d'Histoire et Civilisation de Byzance 16), Paris 
Zuckerman (2004b): Constantin Zuckerman, “Les deux Dioscore d'Aphrodité ou les limites de la pétition”, in: Denis Feissel and Jean Gascou (eds.), La pétition à Byzance (Monographies du Centre de recherche d'Histoire et Civilisation de Byzance 14), Paris, 75-92. 